\title{
Productive and Reproductive Performances of Indigenous Lime and Parkote Buffaloes in the Western hills of Nepal
}

\author{
M. K. Shah ${ }^{1, *}$, Y. Hayashi ${ }^{2}$ and H. Kumagai ${ }^{3}$ \\ ${ }^{1}$ Nepal Agricultural Research Council, Regional Agricultural Research Station, Lumle, Nepal \\ ${ }^{2}$ Experimental Farm, Faculty of Agriculture, Meijo University, Kasugai, 486-0804, Japan \\ ${ }^{3}$ Graduate School of Agriculture, Kyoto University, Kyoto, 606-8502, Japan
}

\begin{abstract}
Livestock is an integral part for the most rural livelihoods in Nepal. A very high proportion of poor and marginalized farmers depend on livestock as main or supplemental resources for their income. Cattle and buffalo contribute to more than $70 \%$ of the livestock sector. The Lime, Parkote and Gaddi are the indigenous buffalo breeds of Nepal. The productive and reproductive performances of indigenous buffalo breeds, Lime and Parkote, were studied in Regional Agricultural Research Station (RARS), Lumle in Nepal. The lactation data of the indigenous buffaloes recorded by RARS livestock farm for 14 years (from 2000 to 2014) was collected and analyzed to assess the production and reproduction traits. The productive performance was $964.0 \pm 33.0$ litre/lactation in Lime and $878.5 \pm 66.3$ litre/lactation in Parkote, while a daily milk yield of Lime was $3.2 \pm 0.1$ litre/day and that of Parkote was $2.9 \pm 0.2$ litre/day. The milk constituents of Lime were $9.0 \%$ fat, $9.2 \%$ solids not fat (SNF) and $3.8 \%$ protein. The milk contents of Parkote were $8.9 \%$ fat, $9.8 \%$ SNF and $4.0 \%$ protein. The maximum mating was found in October $(30 \%)$, while the minimum mating was in June (1\%) in both the breeds. The calving time of Lime and Parkote was maximum in September (36\%). The Lime and Parkote buffaloes are high potential milking animals in the western hills of Nepal. Furthermore, the value chain and organic production approaches would be very useful for the conservation and utilization of these indigenous buffaloes.
\end{abstract}

Keywords: Buffalo, Lime, Parkote, production, reproduction.

\section{INTRODUCTION}

Buffaloes are important livestock commodities in Nepal. There are 5.2 million buffaloes in the country [1]. This animal contributes to about $69 \%$ of milk production and the rest $31 \%$ is come from cattle in Nepal. Buffaloes are integral contributor of food, agricultural power, agrarian culture operation and biodiversity [2]. The buffalo is being suggested as the future species to meet continuously increasing demands for quality milk and meat [3]. Regarding meat production, the $59 \%$ of meat in the nation is come from buffaloes [1]. The indigenous buffalo breeds of Nepal are Lime, Parkote and Gaddi in reverine types with 25 pairs of chromosomes $(2 n=50)$. They are mainly black in colour with certain peculiar marks or patches in the different body parts. The indigenous Lime and Parkote buffaloes are estimated to constitute from $35 \%$ and $25 \%$, respectively, of the total indigenous buffalo population in the country. The milk production of these breeds increased by $3.3 \%$ annually during the last 10 years. This rate is slightly higher than the population growth and indicating productivity improvement [4]. Indigenous buffaloes play a crucial role in the livelihood system and well-being of the traditional rural farmers. These buffaloes breeds have the ability to adapt across

*Address correspondence to this author at the Nepal Agricultural Research Council, Regional Agricultural Research Station, Lumle, Kaski, Nepal; Tel: +977-9849196521; Fax: +977-061522653; Email: manojnarc@yahoo.com different agro-ecological zone, exist in low plain of nutritional regime, efficient forage digestion ability, cold tolerance and relatively smaller body size. They are highly suitable to thrive on narrow and steep slope of the hills and mountains for subsistence type of farming system in the country. In the western Nepal, farmers are disposing buffalo calves, especially the males to save the milk of their dam for home consumption and selling for immediate cash. The survived male calves are the ones whose dam does not give milk. This led to a negative selection to find the effective way to utilize these culled calves and stop negative selection in the herd [5]. However, the utilization of superior genetic materials is restricted due to the indiscriminate breeding and absence of selection. There are limited studies related to improvement of their production potential. Hence, this study was conducted to evaluate the productive and reproductive performances of indigenous Lime and Parkote buffaloes in the western hills of Nepal.

\section{MATERIALS AND METHODS}

\section{Data Collection Site and Animals}

The study was based on data of Lime and Parkote buffaloes maintained at Regional Agricultural Research Station (RARS), Lumle. The RARS, Lumle is situated at $30 \mathrm{~km}$ west from Pokhara, the headquarter of Kaski district. The study site was in the subtropical region, it received highest precipitation in Nepal. The site of the 
study has an agro-meteorological station where the weather data are recorded and maintained on daily basis. An average monthly total rainfall $1763 \mathrm{~mm}$ in August, 2014 and minimum $1 \mathrm{~mm}$ in November, 2015. The maximum temperature was $24.9^{\circ} \mathrm{C}$ in July, 2015 and minimum $5.8^{\circ} \mathrm{C}$ in January, 2015. This research station lies between $28^{\circ} 18^{\prime} \mathrm{N}$ latitude and $83^{\circ} 48^{\prime} \mathrm{E}$ longitude with an elevation of $1675 \mathrm{~m}$ above sea level.

The buffaloes with the first to seventh lactations were used for this survey. The buffaloes were housed in permanent sheds with open type ventilation and maintained under semi-intensive feeding and management conditions. The buffaloes were fed dry roughages (rice straw, wheat straw, millet straw and maize stover) and green fodder (oat, seasonal green grasses, Napier, Raikhanio, Chuletro, Nimaro, Pakhuri and etc.). Available commercial concentrate feeds were provided to fulfill their energy and protein requirements. The supplementary grazing time of the animals was from 11:30 am to $3: 30 \mathrm{pm}$. The buffaloes were hand milked twice in the morning (from 4:30 am to 5:30 am) and evening (from 4:30 pm to $5: 30 \mathrm{pm}$ ). The management of buffaloes and their progenies was performed with routine activities such as feeding, fodder collection, cleaning, grooming, milking, weighing, veterinary care, breeding and etc. Performance records of 14 consecutive years (from 2000 to 2014) were used for this study.

Production and reproductive performance records of the animals. i.e. age at first service, age at first calving, gestation period, lactation length and lactation yield. have been recorded as per standard format. The content of milk fat, solids not fat (SNF) and protein were measured. The data was analyzed using the Minitab statistical package.

\section{RESULTS AND DISCUSSION}

\section{Productive Performance of Indigenous Lime and Parkote Buffaloes}

The productive performances of indigenous Lime and Parkote buffaloes were presented in Table 1. The average lactation yield was 964.0 litre per lactation in Lime and 878.5 litre per lactation in Parkote. The lactation yield of Lime and Parkote buffaloes was ranged from 399.5 to 1311.5 litre and from 473.0 to 1337.8 litre, respectively. The daily mean milk yield of Lime was 3.2 litre and that of Parkote was 2.9 litre. The average daily milk yield of Lime and Parkote buffaloes was ranged from 1.3 to 4.3 litre and from 1.6 to 4.4 litre, respectively. The milk constituents of Lime were $9.0 \%$ fat, $9.2 \%$ SNF and $3.8 \%$ protein. The milk contents of Parkote were $8.9 \%$ fat, $9.8 \%$ SNF and $4.0 \%$ protein. The ranges of milk fat, SNF and protein in Lime buffalo was ranged from $5.1 \%$ to $12.6 \%$, from $6.1 \%$ to $11.2 \%$ and from $2.7 \%$ to $4.6 \%$, respectively. On the other hand, milk milk fat, SNF and milk protein of Parkote ranged from $6.4 \%$ to $11.6 \%$, from $8.8 \%$ to $11.1 \%$ and from $3.3 \%$ to $4.8 \%$, respectively. The other reports of indigenous Lime and Parkote buffaloes produced 2 to 4 litres milk per day [2]. The present study on milk production traits of indigenous buffaloes was supported by research finding of Lime buffaloes [ 6 , 7]. They have well developed udders and prominent milk veins demonstrating the milk type morphological characteristics [8]. The research finding on milk production of Murrah cross buffalo in Terai Nepal was found the average milk fat $7.06 \%$ and SNF $8.91 \%$ [9]. The other research conducted on Murrah cross buffaloes in Terai, Nepal found that the average milk yield was $2.51 \mathrm{~kg}$ per day, whereas milk compositions were $6.31 \%$ fat and $9.08 \%$ SNF [10]. The daily milk yield, fat and SNF concentrations of Lime and Parkote were more than Murrah cross buffaloes raised in Terai

Table 1: Productive Performance of Indigenous Lime and Parkote Buffaloes

\begin{tabular}{|c|c|c|c|c|c|c|}
\hline \multirow{3}{*}{$\mathbf{n}$} & \multicolumn{3}{|c|}{ Lime } & \multicolumn{3}{|c|}{ Parkote } \\
\hline & \multicolumn{3}{|c|}{51} & \multicolumn{3}{|c|}{13} \\
\hline & Mean & Minimum & Maximum & Mean & Minimum & Maximum \\
\hline Daily milk yield (litre) & 3.2 & 1.3 & 4.3 & 2.9 & 1.6 & 4.4 \\
\hline Lactation yield (litre) & 964.0 & 399.5 & 1311.5 & 878.5 & 473.0 & 1337.8 \\
\hline Fat \% & 9.0 & 5.1 & 12.6 & 8.9 & 6.4 & 11.6 \\
\hline Solid not fat \% & 9.2 & 6.1 & 11.2 & 9.8 & 8.8 & 11.1 \\
\hline Protein \% & 3.8 & 2.7 & 4.6 & 4.0 & 3.3 & 4.8 \\
\hline
\end{tabular}


Nepal $[9,10]$. The research finding of Indian Murrah buffaloes showed the concentrations of milk fat, SNF and protein were $8.30 \%, 9.08 \%$ and $3.08 \%$, respectively [11]. Our findings were similar to those reported by Pawar et al. [11]. The other survey report on milk production traits of Murrah cross buffaloes in Nepal showed the lactation milk yield and daily milk yield were $1560.8 \mathrm{~kg}$ and $4.5 \mathrm{~kg}$, respectively [12]. The present report of indigenous buffaloes showed lower lactation milk yield and daily milk yield than the survey of Murrah cross buffaloes [12]. The total milk yield of Murrah, Surti and Nili-Ravi buffaloes in the intermediate zone of Sri Lanka was $1249 \mathrm{~kg}, 1187 \mathrm{~kg}$ and $1197 \mathrm{~kg}$, respectively [13]. The milk yield performance of Murrah, Nili-Ravi and Surti buffalo was higher than the Lime and Parkote buffalo. The difference in the milk production traits, reported by various survey reports, might be due to genetic constitution of the herds, climatic variations and management conditions. In general, the performance in terms of lactation milk yield of Lime and Parkote buffaoles at RARS is higher than the performance reported elsewhere earlier regarding those breeds.

\section{Reproductive Performance of Indigenous Lime and Parkote Buffaloes}

The reproductive performances of indigenous Lime and Parkote buffaloes were presented in Table 2. The age at first service (days), age at first calving (days), gestation period (days), lactation length (days), dry period (days) and calving interval (days) were found as $978.1 \pm 172.8,1333.9 \pm 189.3,304.1 \pm 6.6,303.6 \pm 71.6$, $176.9 \pm 22.1$ and $489.4 \pm 66.1$, respectively. These results were shorter than the past survey report that showed the age of first calving of Lime and Parkote buffaloes was 51.6 months [6]. The age of the first calving of indigenous buffalo was reported to be 53.8 months [14]. According to the study undertaken at RARS, Lumle, the overall age at first calving, the days of the first service after calving and calving interval of the indigenous buffalos were found to be 55.2 months, 175 days and 529 days, respectively [15]. The dry period of Murrah, Nili-Ravi, and Surti buffaloes were reported to be 180 days, 181 days and 185 days in the intermediate zone of Sri Lanka, respectively [13]. The survey of Nepal on Murrah cross buffalo reported that the calving interval and dry period was 653.9 days and 310.7 days, respectively [12]. The mean calving interval of present study was longer than the report of Murrah buffaloes. The reproductive performance of Lime and Parkote was better than the previous research report, due to the genetic constitution of the buffalo breeds, environmental variations and a variety of the feeding management of the animals.

Table 2: Reproductive Performance of Indigenous Lime and Parkote Buffaloes

\begin{tabular}{|c|c|}
\hline Traits & Mean \pm SD \\
\hline \hline Age at first service (days) & $978.1 \pm 172.8(n=57)$ \\
\hline Age at first calving (days) & $1333.9 \pm 189.3(n=57)$ \\
\hline Gestation Period (days) & $304.1 \pm 6.6(n=70)$ \\
\hline Lactation length (days) & $303.6 \pm 71.6(n=69)$ \\
\hline Dry Period (days) & $176.9 \pm 22.1(n=56)$ \\
\hline Calving interval (days) & $489.4 \pm 66.1(n=51)$ \\
\hline
\end{tabular}

\section{Mating and Calving Month of the Buffaloes Breeds Raised in Nepal}

The rate of mating and calving of indigenous Lime and Parkote buffaloes was presented in Figure 1. The mating and calving month of indigenous Lime and Parkote buffaloes were ranged throughout a year. However the relative high rate of mating and calving were from August to November and from June to September, respectively. The past survey of the mating and calving in the indigenous buffaloes showed that the highest rate of mating and calving was detected from August to November and from June to September, respectively [16]. The mating of buffalo was from June to November at pasture area where male and female buffalo grazing together; the calving month of buffalo was from July and September in the hilly mountain regions when the pasture and forage abundant available [17].

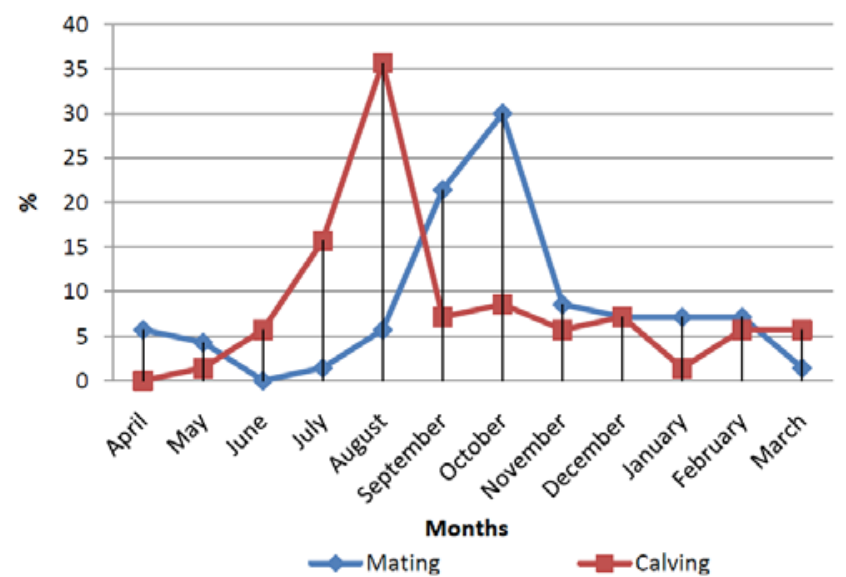

Figure 1: Rate of mating and calving of indigenous Lime and Parkote Buffaloes.

In conclusion, the milk production of Lime and

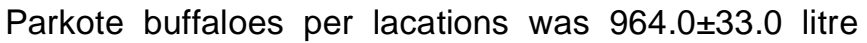


and $878.5 \pm 66.3$ litre, respectively. The fat concentration of Lime and Parkote buffaloes was $9.0 \%$ and $8.9 \%$, respectively. The maximum mating and calving months in indigenous buffaloes were from August to November and from June to September, respectively. Results obtained from this study have shown variation in reproductive and productive performances of indigenous Lime and Parkote buffaloes. In general, milk production of the Lime buffaloes in the herd under study was comparatively higher than the performance of Parkote buffaloes. Adoptions of proper selection appropriate breeding methods are essential for its genetic improvement to increase its productivity.

\section{ACKNOWLEDEMENTS}

The authors gratefully acknowledge D. B. Gharti, Y. K. Shrestha, K. P. Dhungana, B. R. Acharya, P. L. Adhikari, D. N. Devkota, H. Ichimura and the staffs of Regional Agricultural Research Station, Lumle, Kaski, Nepal for collection the data and technical assistance in this study periods.

\section{REFERENCES}

[1] Statistical Information on Nepalese Agriculture (SINA). AgriBusiness Promotion and Statistical Division. Ministry of Agriculture and Co-operatives, Kathmandu, Nepal 2014; pp. 39-44.

[2] Neopane SP. Characterization of indigenous animal genetics resources of Nepal. Proceeding of the 6th National Worshop on Livestock and Fisheries Research. Nepal Agricultural Research Council 2006; pp. 1-11.

[3] Arora R, Lakhchaura BD, Prasad RB, Tantia MS, Vijh RK. Genetic diversity analysis of two buffalo populations of northern India using microsatellite markers. Anim Gen 2004; 121: 111-8.

http://dx.doi.org/10.1111/j.1439-0388.2004.00451.x

[4] Neopane SP, Shrestha BS. Genetic improvement of buffalo in Nepal. 6th Asian Buffalo Congress, Lahore, Pakistan, Pakistan J Zoology 2009; (Suppl. 9): 459-5.

[5] Rana RS, Amatya A, Shrestha HR. Effect of concentrate feeding on meat production of local male buffalo calves. Proceeding of the 4th National Workshop on Livestock and Fisheries Research in Nepal 2000; pp. 132-9.
[6]

Amatya N, Rasali DP, Rana RS. Evaluation of phenotypic and production characteristics of indigenous buffalo type in the western hills of Nepal. Nepal Agricultural Research Council, Lumle, Nepal. Technical Report 2000; p. 16.

[7] Rasali DP, Joshi HD, Patel RK, Harding AH. Phenotypic clusters and karyotypes of indigenous buffaloes in the Western Hills of Nepal. Lumle Agricultural Research Station, Pokhara, Nepal. Technical Paper 1998b; 98/2: p. 24.

[8] Pokharel PK, Kuwar BS, Shrestha NP, Neopane SP, Shrestha HR. Identification, Characterization and conservation strategy of Gaddi buffalo. Proceeding of the 4th Global Conference of Domestic Animal Genetic Resources 1998; pp. 77-80.

[9] Hayashi $Y$, Devkota NR, Kumagai $H$. Effect of field pea (Pisum sativum L.) hay feeding on dry matter intake and milk production of Murrah buffaloes (Bubalus bubalis) fed rice straw ad libitum. Anim Sci J 2007; 78: 151-8. http://dx.doi.org/10.1111/.1740-0929.2007.00419.x

[10] Hayashi Y, Thapa BB, Sharma MP, Sapkota M, Kumagai H. Effect of maize (Zea mays L.) silage feeding on dry matter intake and milk production of dairy buffalo and cattle in Tarai, Nepal. Anim Sci J 2009; 80: 418-27. http://dx.doi.org/10.1111/j.1740-0929.2009.00655.x

[11] Pawar HN, Ravi Kumar GVPPS, Narang R. Effect of year and parity on milk production traits in Murrah buffaloes. J Buffalo Sci 2013; 2: 98-102.

[12] Hayashi $Y$, Shah MK, Kumgai $H$. Changes of milk production and reproductive performance of dairy buffaloes in Nepal during recents 15 years; J Buffalo Sci 2014; 3: 34-7. http://dx.doi.org/10.6000/1927-520X.2014.03.02.1

[13] Charlini BC, Sinniah J. Performance of Murrah, Surti, NiliRavi buffaloes and their crosses in the intermediate zone of Sri Lanka. Livest Res for Rural Dev. Volume 27, Article \#47. [Retrieved March 14, 2016] Available from: http://www.Irrd.org//rrd27/3/char27047.html

[14] Rasali DP, Gurung DB, Yadav ER. Performance of monsoon calver buffaloes across genotypic and non-genotypic factors under farmers management in western hills districts of Nepal, Lumle Agricultural Research Centre, Pokhara, Nepal. Working Paper 1997; 96/39; p. 19.

[15] Rasali DP, Gurung DB, Yadav ER. Performance recording of lactating local and crossbred cows and buffaloes of various exotic breed blood levels under farmers management in the Western Hills Lumle Agricultural Research Centre, Pokhara, Nepal 1997; p. 17.

[16] Shrestha BS. Development of suitable breeding strategy for indigenous buffaloes in the western hills of Nepal. Final Technical Report, HARP 2003; p. 78.

[17] Moioli B, Borghese A. Buffalo breeds and Management systems In: Buffalo Production and Research (Ed.) By Borghese Antonio (REU Technical Series 67), Food and Agricultural Organization of the United Nations 2005; p. 37. 